\title{
Cataract and Diabetes
}

\author{
F. I. CAIRD,* D.M., M.R.C.P.; MARY HUTCHINSON ; ANTOINETTE PIRIE, † M.A., PH.D.
}

Brit. med. F., 1964, 2, 665-668

Review of the literature reveals much confusion over the relation between cataract and diabetes in the older age-groups. Table I shows that in ophthalmoscopic surveys cataract has as often as not been found to be commoner in non-diabetics than in diabetics. Surveys of patients who have had a cataract extracted have, on the other hand, shown an overall proportion of diabetics that is higher than any reported percentage in a general population.

TABLE I.-Previous Studies of the Relation Between Diabetes and Cataract

\begin{tabular}{l|l|l|l}
\hline (a) Author & No. of Subjects & Age & $\%$ with \\
\hline
\end{tabular}

(a) Ophthalmoscopic examination for cataract

\begin{tabular}{|c|c|c|c|c|c|}
\hline Waite and Beetham & (1935) & $\begin{array}{l}\text { Diabetics .. } \\
\text { Non-diabetics }\end{array}$ & $\begin{array}{l}.4,001 \\
\because .914\end{array}$ & $\begin{array}{r}\text { Over } 20 \\
\Rightarrow 20\end{array}$ & $\begin{array}{l}45 \cdot 0 \\
57 \cdot 0\end{array}$ \\
\hline Heinsius and Arndt & (1950) & $\begin{array}{l}\text { Diabetics . } \\
\text { Non-diabetics }\end{array}$ & $\begin{array}{l}. \quad 223 \\
\therefore \quad 331\end{array}$ & $\Rightarrow 50$ & $\begin{array}{l}29 \cdot 0 \\
20 \cdot 0\end{array}$ \\
\hline Dollfus (1954) & . & $\begin{array}{l}\text { Diabetics . } \\
\text { Non-diabetics }\end{array}$ & .. 954 & $\dddot{345}$ & $\begin{array}{r}5.9 \\
14.5\end{array}$ \\
\hline Kato et al. (1960) & .. & $\begin{array}{l}\text { Diabetics ... } \\
\text { Non-diabetics }\end{array}$ & $\begin{array}{l}. \quad 175 \\
. . \quad 296\end{array}$ & $\Rightarrow 45$ & $\begin{array}{l}30 \cdot 2 \\
12 \cdot 8\end{array}$ \\
\hline ulloch (1962) & .. & $\begin{array}{l}\text { Diabetics . } \\
\text { Non-diabetics }\end{array}$ & $\begin{array}{l}. \quad 250 \\
\therefore \quad 250\end{array}$ & $\Rightarrow \quad 20$ & $\begin{array}{l}25.0 \\
11.0\end{array}$ \\
\hline
\end{tabular}

\begin{tabular}{l|l|l}
\hline (b) $\quad$ Author & No. of Extractions & No. of Diabetics \\
\hline
\end{tabular}

(b) Cataract extractions

\begin{tabular}{|c|c|c|c|}
\hline \multirow{2}{*}{$\begin{array}{l}\text { Clegg (1920) } \\
\text { Anthonisen (1936) } \\
\text { Townes and Casey (1955) }\end{array}$} & \multicolumn{2}{|c|}{ (b) Cataract extractions } & \multirow[b]{2}{*}{$\begin{array}{r}87(5 \%) \\
138(8 \%) \\
130(7 \%)\end{array}$} \\
\hline & & $\begin{array}{l}1,660 \\
1,717 \\
1,844\end{array}$ & \\
\hline
\end{tabular}

The purpose of the present investigation was to define as accurately as possible the true prevalence of diabetes in a group of adult patients who had a senile cataract extracted; to assess whether or not, as it is sometimes stated (Beckett and Hobbs, 1961), cataract develops at an earlier age in diabetics ; to estimate the frequency with which undiscovered diabetics present with cataract in an Eye Department ; and to study, in diabetics who had had a cataract extracted, the age at diagnosis, and the duration and control of diabetes. The relevance of control of diabetes has been strongly suggested by work on the metabolism of the lens (van Heyningen, 1959, 1962).

\section{Methods}

A study was made of the case records of all patients over the age of 20 who had had a cataract extracted in the Oxford Eye Hospital in the six years 1957 to 1962 .

\section{Definitions}

Cataract in both diabetics and non-diabetics was considered non-senile when it was thought to have a congenital basis or when it occurred in association either with other possibly causal ocular disease, in particular trauma, uveitis, and glaucoma, or with general disease other than diabetes. All other cataracts were regarded as " senile."

Diabetes was diagnosed on customary biochemical criteria. All patients had their urine tested for sugar at least once.
Proved diabetics were considered to have been found as a result of cataract when the principal symptom leading to the diagnosis of diabetes was impairment of vision due to cataract. All other diabetics, including those whose diabetes was diagnosed as a result of ocular symptoms other than those of cataract, were considered "known diabetics."

Control of diabetes was assessed from the proportion of urine tests which showed $2 \%$ or more sugar in Benedict's test on routine attendance at the Radcliffe Infirmary Diabetic Clinic. Of the diabetics who had had a cataract extracted, only those who had attended the clinic on five or more occasions before their operation were considered. They were compared with 100 diabetics chosen at random from those at present attending the clinic who had also attended five or more times. No attempt was made to match this random group with the patients who had had a cataract extraction, since previous experience had shown that such attempts result in much bias (Caird, 1961).

Domicile.-Patients were divided by their address at the time of operation into two groups, those living outside and those living inside an area (Fig. 1) from which it is virtually certain that all ophthalmic operations are carried out in the Oxford Eye Hospital. There are no other hospitals in the area where ophthalmic operations are done.

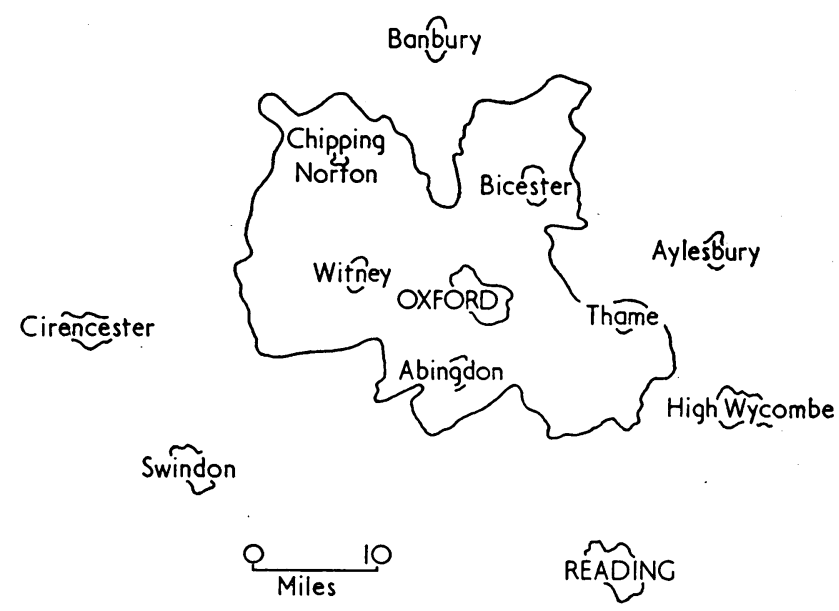

FIG. 1.-Sketch map of defined area.

The total civilian population in 1961 of the area defined is estimated as 284,000 (General Registry Office, 1961). The population of each part of the area in each quinquennial age and sex group at the 1951 Census (General Registry Office, 1954) was multiplied by a factor for the growth of population between 1951 and 1961 specific for each part of the area and calculated from the ratio of the estimated total population of that part of the area in 1961 (General Registry Office, 1961) to the population at the 1951 Census (General Registry Office, 1954). The sum of the estimates for each part of the area was used as the estimated population of the whole area in each age and sex group.

* Medical Tutor, Radcliffe Infirmary, Oxford.

+ Margaret Ogilvie's Reader in Ophthalmology, Nuffield Laboratory of Ophthalmology, University of Oxford. 


\section{Results}

There were 1,485 cataract extractions ${ }^{1}$ in the period under review and 1,281 patients, of whom $123(9.6 \%)$ were diabetics. Of these operations 159 were for non-senile cataract as defined, on 143 patients, of whom $8(5.6 \%)$ were diabetics. The cataract was associated with glaucoma in 71 patients ( 5 diabetics), with uveitis of all types in 30 ( 3 diabetics), with trauma in 25 ; all other causes accounted for 19 . The elimination of these nonsenile cataracts leaves 1,326 operations for senile cataract as defined, on 1,138 patients, of whom $115(10.1 \%)$ were diabetics.

Since the indications for operation on the first and second eye may differ, and may differ in diabetics and non-diabetics, the 302 second operations were excluded from further consideration. We also eliminated those 114 patients, of whom five $(4.4 \%)$ were diabetics, on whom only the second operation was carried out in the period under review. This leaves 1,024 patients, of whom $110(10.7 \%)$ were diabetics, who had their first extraction of a senile cataract. Table II shows the both in diabetics and in non-diabetics. Cataract extraction is between four and six times commoner in known diabetics than in non-diabetics. It is doubtful whether the relatively higher rates in diabetics in the 50-69 age-group can be accepted as

TABLE V.-Relative Frequency of First Senile Cataract Extraction in Non-diabetics and Known Diabetics Living in the Area

\begin{tabular}{|c|c|c|c|c|}
\hline & \multicolumn{2}{|c|}{$50-69$} & \multicolumn{2}{|c|}{70 and Over } \\
\hline & $M$ & F & $\mathbf{M}$ & F \\
\hline $\begin{array}{lll}\text { Estimated total population } . . & . & \\
\text { Known diabetics }(\%))^{*} \\
\text { Estimated No. of known diabetics } & . & \end{array}$ & $\begin{array}{c}24,340 \\
1.08 \\
263\end{array}$ & $\begin{array}{c}29,920 \\
1.35 \\
404\end{array}$ & $\begin{array}{l}7,370 \\
1.54 \\
114\end{array}$ & $\begin{aligned} 10,210 \\
1.96 \\
200\end{aligned}$ \\
\hline 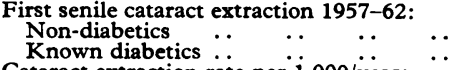 & $\begin{array}{r}67 \\
4\end{array}$ & $\begin{array}{r}93 \\
9\end{array}$ & $\begin{array}{r}85 \\
6\end{array}$ & $\begin{array}{r}183 \\
19\end{array}$ \\
\hline 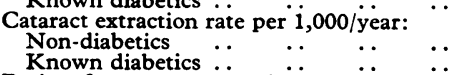 & $\begin{array}{r}4 \\
0.5 \\
2.5\end{array}$ & $\begin{array}{l}0.6 \\
3.7\end{array}$ & $\begin{array}{r}0 \\
1.9 \\
8 \cdot 8\end{array}$ & $\begin{array}{r}19 \\
3 \cdot 0 \\
15 \cdot 8\end{array}$ \\
\hline $\begin{array}{l}\text { Ratio of cataract extraction rates: known } \\
\text { diabetics/non-diabetics } \ldots\end{array}$ & 5.0 & 6.2 & $4 \cdot 6$ & $5 \cdot 3$ \\
\hline
\end{tabular}

* Working Party (1962), personal communication.

TABLE II.-Patients with First Operation for Senile Cataract

\begin{tabular}{|c|c|c|c|c|c|c|c|c|c|c|c|c|c|c|c|c|c|c|}
\hline & \multicolumn{2}{|c|}{$30-39$} & \multicolumn{2}{|c|}{$40-49$} & \multicolumn{2}{|c|}{ 50-59 } & \multicolumn{2}{|c|}{ 60-69 } & \multicolumn{2}{|c|}{ 70-79 } & \multicolumn{2}{|c|}{$80-89$} & \multicolumn{2}{|c|}{ 90-99 } & \multicolumn{2}{|c|}{ Total } & \multirow{2}{*}{ Total } & \multirow{2}{*}{$\begin{array}{c}\% \\
\text { Dia- } \\
\text { betics }\end{array}$} \\
\hline & $\mathbf{M}$ & $\mathbf{F}$ & $M$ & $F$ & $M$ & $F$ & $\mathbf{M}$ & F & $\mathbf{M}$ & $\mathbf{F}$ & $M$ & $\mathbf{F}$ & $M$ & $\mathbf{F}$ & $M$ & F & & \\
\hline $\begin{array}{l}\text { No. of patients } \\
\text { Diabetics: }\end{array}$ & 3 & 1 & 13 & 14 & 55 & 57 & 84 & 160 & 154 & 268 & 74 & 131 & 3 & 7 & 386 & 638 & 1,024 & \\
\hline $\begin{array}{l}\text { Known } \\
\text { Found } \\
\text { Total }\end{array}$ & $\begin{array}{l}1 \\
0 \\
1\end{array}$ & $\begin{array}{l}0 \\
0 \\
0\end{array}$ & $\begin{array}{l}0 \\
0 \\
0\end{array}$ & $\begin{array}{l}4 \\
1 \\
5\end{array}$ & $\begin{array}{l}3 \\
1 \\
4\end{array}$ & $\begin{array}{r}6 \\
4 \\
10\end{array}$ & $\begin{array}{l}5 \\
2 \\
7\end{array}$ & $\begin{array}{r}16 \\
5 \\
21\end{array}$ & $\begin{array}{l}3 \\
5 \\
8\end{array}$ & $\begin{array}{l}27 \\
10 \\
37\end{array}$ & $\begin{array}{l}5 \\
2 \\
7\end{array}$ & $\begin{array}{r}9 \\
1 \\
10\end{array}$ & $\begin{array}{l}0 \\
0 \\
0\end{array}$ & $\begin{array}{l}0 \\
0 \\
0\end{array}$ & $\begin{array}{l}17 \\
10 \\
27\end{array}$ & $\begin{array}{l}62 \\
21 \\
83\end{array}$ & $\begin{array}{r}79 \\
31 \\
110\end{array}$ & $\begin{array}{r}7.7 \\
3.0 \\
10 \cdot 7\end{array}$ \\
\hline
\end{tabular}

distribution by age and sex of these 1,024 patients. The figures also show that $3 \%$ (31 out of 1,024$)$ of all patients who had their first operation for senile cataract were previously undiscovered diabetics.

Table III shows that the visual indications for operation in the diabetics and non-diabetics were identical.

TABLE III.-Pre-operative Visual Acuity in First Operation for Senile Cataract

\begin{tabular}{|c|c|c|c|}
\hline & & Non-diabetic & Diabetic \\
\hline $\begin{array}{l}\text { No. of patients } . \\
\text { Visual acuity }\left\{\begin{array}{l}\text { Less than } 6 / 60 \\
6 / 60 \text { to } 6 / 18 \\
6 / 12 \text { or better }\end{array} \cdots\right.\end{array}$ & $\begin{array}{l}. \\
\because \\
\because\end{array}$ & $\begin{array}{l}904 \\
745(82 \%) \\
150(17 \%) \\
9(1 \%)\end{array}$ & $\begin{array}{l}108 \\
89(82 \%) \\
18(17 \%) \\
1(1 \%)\end{array}$ \\
\hline
\end{tabular}

Pre-operative visual acuity not known in 10 non-diabetics and in 2 diabetics.

The overall prevalence of known diabetics among a group of adult patients, defined as closely as possible by type of cataract, operation, and domicile, is $8.8 \%$ (Table IV). Nearly one-third (19 out of 59) of the diabetics living in the area were found as a result of cataract. The inclusion of these brings the proportion of diabetics among patients living in the area up to $13 \%$ (Table IV).

Table $\mathrm{V}$ shows a calculation of the relative frequency of first extraction of a senile cataract in the age-groups 50 to 69 and over 70 in known diabetics and non-diabetics living in the area. The number of known diabetics was estimated from the prevalence of known diabetics in the general population (Working Party, 1962). The annual rates of cataract extraction rise sharply with age, and are higher in women than in men,

${ }^{1}$ Detailed tables showing the distribution by age and sex of all patients in each subgroup are available on reçuest. definite evidence of a younger age at cataract extraction in diabetics.

Fig. 2 shows the age at diagnosis of diabetes and the duration of diabetes at the time of the first cataract extraction in the 110 diabetics with senile cataract. Also shown are 126 diabetics with retinal haemorrhages and/or exudates, with or without microaneurysms (Caird and Garrett, 1962), and 134 diabetics with persistent proteinuria, due in the great majority to diabetic nephropathy (Caird, 1961). The duration of diabetes shown is that at the time of first diagnosis of retinopathy on routine ophthalmological examination, and at the time of first appearance of proteinuria, respectively. The pattern is very similar in all three groups, with a clear relation between long duration of diabetes and diagnosis of diabetes early in life. But, in general, the age at diagnosis of diabetes and the duration of diabetes tend to be greater in the patients with a cataract extraction than in the others.

Table VI compares control of diabetes in the 45 known diabetics who had had a cataract extracted and the 100 diabetics chosen at random who fulfilled the requirements listed. The proportion of patients with a high frequency of $2 \%$ glycosuria is significantly greater (at the $1 \%$ level) among those who had had a cataract extracted.

TABLE VI.-Effect of Control of Diabetes

\begin{tabular}{|c|c|c|c|c|}
\hline & \multirow{2}{*}{$\begin{array}{c}\text { No. of } \\
\text { Patients }\end{array}$} & \multicolumn{3}{|c|}{$\begin{array}{c}\text { Percentage of Routine Clinic } \\
\text { Urine Tests showing } 2 \% \\
\text { Glycosuria }\end{array}$} \\
\hline & & $<20 \%$ & $20-40 \%$ & $>40 \%$ \\
\hline $\begin{array}{l}\text { Diabetics with cataract extr } \\
\text { "Random" diabetic clinic }\end{array}$ & $\begin{array}{r}45 \\
100 \\
\end{array}$ & $\begin{array}{l}17 \\
63 \\
\end{array}$ & $\begin{array}{l}10 \\
28\end{array}$ & $\begin{array}{r}18 \\
9\end{array}$ \\
\hline
\end{tabular}

$\chi^{2}=15 \cdot 2 ;$ d.f. $=2 ; \mathbf{P}<0.01$

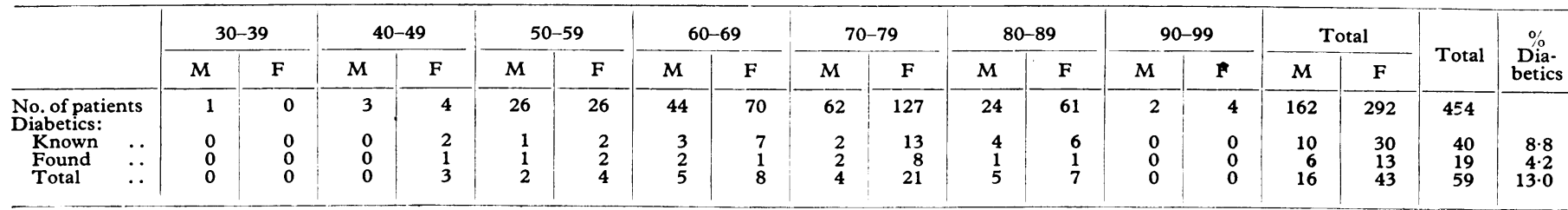




\section{Discussion}

Among 454 patients who had had their first operation for senile cataract and lived within a defined area, the proportion of known and found diabetics is $13 \%$, and of known diabetics $8.8 \%$. These figures are derived from groups of diabetics and non-diabetics very closely comparable as regards type of cataract, operation, pre-operative visual acuity and domicilefactors which do not appear to have been taken into account in previous studies. The identity of pre-operative visual acuity in diabetics and non-diabetics (Table III) suggests that the close supervision of diabetes has little influence on the acceptance of patients for operation.

The number of diabetics operated on for cataract may be affected in two ways by the presence of diabetic retinopathy. Operation may be denied to a patient because retinopathy is

IIO DIABETICS WITH CATARACT EXTRACTION
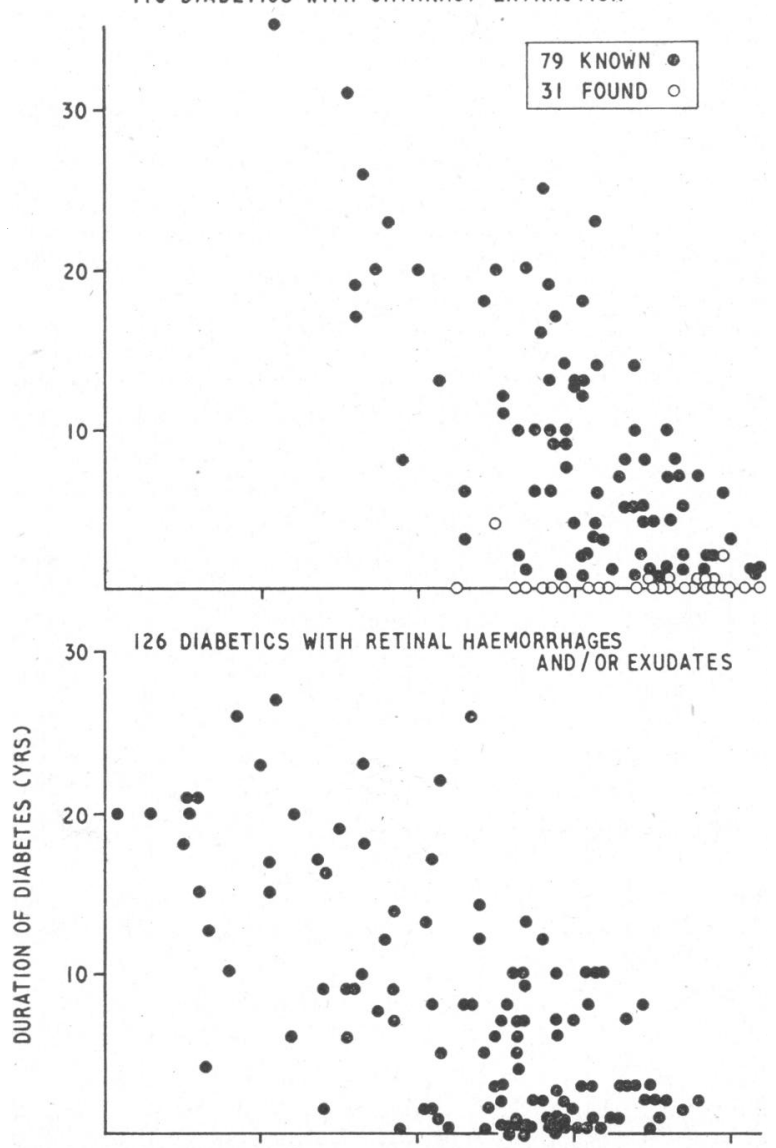

134 DIABETICS WITH PROTEINURIA

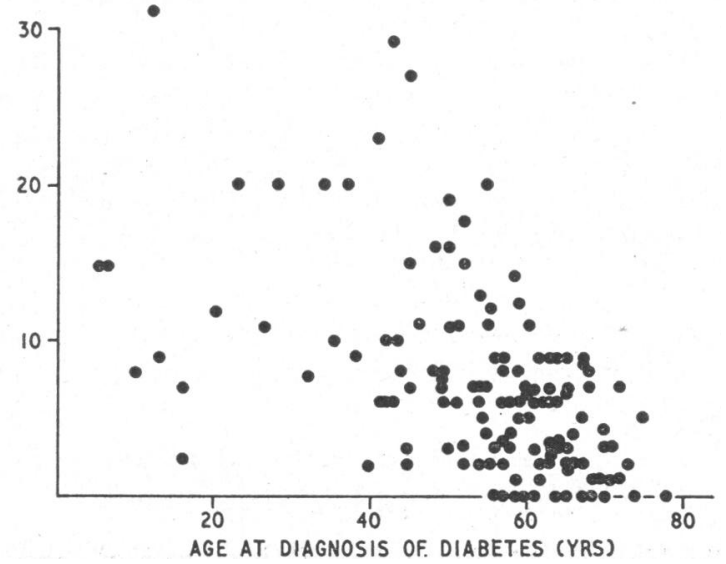

FIG. 2.-Comparison of duration of diabetes and of age at diagnosis in 110 diabetics who had a senile cataract extracted, in 126 with retinopathy, and in 134 with persistent proteinuria. thought to preclude a worth-while operative result, and, per contra, a cataract of less severity than would ordinarily warrant extraction may be extracted if the patient has retinopathy, in order to make the best use of remaining retinal function. These two factors will clearly influence, in opposite directions, the number of diabetics operated on for cataract. Neither can be accurately measured, but there is no good evidence that either was important in the decision to extract a lens from a diabetic. Our figures may therefore reasonably be compared with those found by others (Table I, b). The overall proportion of $13 \%$ is substantially higher than others give for the percentage of diabetics among patients having a cataract extracted. The percentage of known diabetics $(8.8 \%)$ is more nearly equivalent.

Previous investigators have not distinguished between known diabetics and those found as a result of cataract. If the diabetics in the general population and among patients having a cataract extracted are to be compared, the comparison is best made on the basis of the known diabetics in the two groups, because patients whose diabetes is found as a result of cataract are more nearly comparable to the diabetics in the general population who may be found as a result of a diabetic survey. The number of the latter will depend in particular on the exact definition of diabetes used, and the methods employed to establish the diagnosis. The definition of "known diabetics" is much more secure.

The estimate of relative frequency of cataract extraction in known diabetics and non-diabetics (Table V) is subject to errors in the derivation, (1) of the total population of the area (see Methods), (2) of the number of known diabetics (because of the use of figures for the prevalence of diabetes established in another population), and (3) of the rate of cataract extraction in diabetics (because of the relatively small number of diabetics living in the area who had a cataract extracted). But it would seem reasonable to accept that extraction of senile cataract, as defined, is between four and six times commoner in known diabetics than in non-diabetics of both sexes. The comparable figure given by Anthonisen (1936) for patients over 55 is fifteen to twenty times. The difference is doubtless due in large part to the low prevalence of known diabetes $(0.13 \%)$ in the general population used by him. We cannot demonstrate an earlier age at cataract extraction in diabetics, perhaps because of the small numbers of known diabetics below the age of 70 in our series (Table V).

There is a clear contradiction in Table $I$ between the frequent failure to find an excess of cataracts in diabetic patients examined ophthalmoscopically and the constant finding of an excess of diabetics among patients who had had a cataract extracted. This may perhaps be resolved by the assumption of what is often stated as a fact (Parsons, 1954), that vataract matures more rapidly in diabetics.

Fig. 2 indicates that long duration of diabetes is important in the development of cataract of sufficient severity to warrant extraction, though in older diabetics who have a cataract extracted cataract is the presenting feature in as many as one-third (Table III). Retinopathy and proteinuria, both customarily regarded as complications of long-term diabetes, may also be found in patients of the same age with newly discovered diabetes (Fig. 2 ; and Pyke and Roberts, 1959 ; Lambie and Macfarlane, 1955). In all three instances the relation between the age at diagnosis of diabetes and duration of diabetes may reflect a more rapid progression of the complication in older diabetics (Caird and Garrett, 1962).

The effect of poor control of diabetes in the genesis of true diabetic cataract has been suggested by clinical studies (O'Brien, Molsberry, and Allen, 1934) and by experimental work in the rat (Patterson, 1951). Our findings (Table VI) suggest that the development of cataract in the older diabetic is also influenced by control of the diabetes. That control of the blood-sugar level should have particular relevance for maintenance of clarity of the lens is reasonable from a consideration of its peculiar metabolism (van Heyningen, 1959, 1962; Pirie and van 
Heyningen 1964). There thus exists at least the theoretical possibility of prevention, or delay in maturation, of cataract in some patients, by early diagnosis and scrupulous control of the diabetes.

Some 16,750 patients over 45 have a cataract extracted each year in England and Wales (Sorsby, 1962). If $13 \%$ of these are diabetics, the annual number of operations on diabetics is 2,180 . At least $3 \%$ of all patients having a senile cataract extracted are previously undiscovered diabetics (Table IV). Thus some 440 diabetics will be diagnosed each year in England and Wales on account of cataract alone. Routine urine-testing of all patients with senile cataract, on their first attendance and on as many subsequent occasions as possible, would seem obligatory, together with detailed investigation of any with even a trace of reducing substance in their urine.

\section{Summary}

A review has been made of 1,485 cataract extractions carried out in the Oxford Eye Hospital in the years 1957-62. First operations for senile cataract numbered 1,024, and $110(10.7 \%)$ of these were on diabetics.

Diabetes was found as a result of cataract in $31(28 \%)$ of the 110 diabetics, or $3 \%$ of all patients having a senile cataract extracted.

A total of 454 patients lived within a defined area. Of these, $13 \%$ were diabetics, and $8.8 \%$ previously known diabetics. Extraction of a senile cataract was calculated to be four to six times more frequent in known diabetics than in non-diabetics.

Senile cataract in known diabetics tends to be associated with diabetes of long duration.

The degree of control of diabetes in patients having a cataract extracted was worse than the average in those attending a diabetic clinic.
These findings are briefly discussed in the light of the known peculiarities of glucose metabolism in the lens.

It is a pleasure to thank Mr. J. P. F. Lloyd, Mr. A. C. L. Houlton, Mr. V. B. Purvis, and Dr. A. M. Cooke for permission to study their patients. Thanks are also due to them and to $\mathrm{Mr}$. M. H. Luntz, Dr. T. B. Stephens, Dr. D. Sevel, Miss B. Bullard, Mr. J. M. D. Burns, Dr. E. D. Acheson, and Dr. J. G. Evans for assistance, advice, and criticism.

\section{REFERENCES}

Anthonisen, H. (1936). Acta Ophthal. (Kbh.), 14, 150

Beckett, A. G., and Hobbs, H. E. (1961). Brit. med. f., 2, 1605. Caird, F. I. (1961). Diabetes, 10, 178.

C and Garrett, C. J. (1962). Proc. roy. Soc. Med., 55, 477.

Clegg, J. G. (1920). Trans. ophthal. Soc. U.K., 40, 37.

Dollfus, M. (1954). Bull. Soc. Ophtal. Fr., 67, 62 .

General Registry Office (1954). Census, 1951, England and Wales. County Reports, Oxfordshire and Berkshire. H.M.S.O., London. (1961). Census, 1961, England and Wales. Preliminary Report, Table 2. H.M.S.O., London.

Heinsius, E., and Arndt, G. (1950). Albrecht v. Graefes Arch. Ophthal., $150,555$.

Kato, K., Amaha, E., Hagai, A., and Martin, M. (1960). Acta soc.

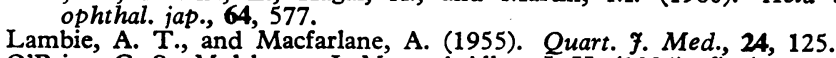

O'Brien, C. S., Molsberry, J. M., and Allen, J. H. (1934). Ұ. Amer. med. Ass., 103, 892.

Parsons, J. (1954). Diseases of the Eye, 12th ed., edited by W. S. DukeElder, p. 264. Churchill, London.

Patterson, J. W. (1951). Amer. F. Physiol., 165, 61.

Pirie, A., and van Heyningen. R. (1964)., Exp. Eye Res., 3

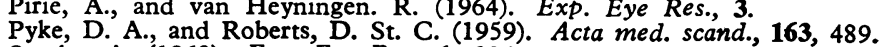
Sorsby, A. (1962). Exp. Eye Res., 1, 296.

Townes, C. D., and Casey, E. R. (1955). Sth. med. F. (Bgham, Ala.), 48, 844.

Tulloch, J. A. (1962). Diabetes Mellitus in the Tropics. Livingstone, Edinburgh.

van Heyningen, R. (1959). Nature (Lond.), 184, 194.

(1962). Exp. Eye Res., 1, 396

Waite, J. H., and Beetham, W. P. (1935). New Engl. f. Med., 212, 367,

Working Party (1962). Brit. med. f., 1, 1497.

\title{
Lymphoma Syndrome in Northern Nigeria
}

\author{
C. G. BERRY,* M.D., D.C.P., M.C.PATH.
}

Brit. med. F., 1964, 2, 668-670

Over recent years the prevalence of a malignant lymphoma in children living in tropical Africa has received much attention. The syndrome described by Burkitt (1958) and by Burkitt and O'Conor (1961) primarily affects non-lymphoid tissues, most commonly presenting as a destructive lesion involving the mandible, maxilla, and face, and may on occasion appear to be multicentric. Burkitt (1962a, 1962b) has observed that in certain parts of tropical Africa this is the commonest malignant tumour of childhood, but that it seems to be limited to areas at an altitude of less than $5,000 \mathrm{ft}$. $(1,524 \mathrm{~m}$.), with a yearly rainfall of more than $20 \mathrm{in}$. $(50.8 \mathrm{~cm}$.), and where the temperature does not fall below $60^{\circ} \mathrm{F} .\left(15.5^{\circ} \mathrm{C}\right.$.) during the coldest season of the year. In fact, this geographic distribution corresponds with that of certain mosquito-borne diseases such as malignant tertian malaria and yellow fever. This observation, along with the apparent multifocal origin of the tumours in some cases, the recognition of the tumour in non-African children living in the areas described, and the age incidence (2-14 years, with a maximum incidence between 5 and 8 years) led to the hypothesis that the tumour might be of virus origin,

* Regional Pathology Laboratory, Kaduna, Northern Nigeria. possibly carried by an arthropod vector. A team from the Virus Research Laboratory, Mill Hill, London, is at present working with the East African Virus Research Institute in Entebbe to investigate this possibility.

Burkitt's tumour is known to occur commonly in those parts of West Africa where the optimal conditions of temperature and humidity apply. Edington and Maclean (1964) have discussed the incidence of the lesion in Ibadan, and earlier accounts of tumours in West Africa include descriptions of what would seem to be the same lesion (Smith and Elmes, 1934 ; Elmes and Baldwin, 1947 ; Edington, 1956). There is no account of the occurrence of Burkitt's tumour in Northern Nigeria, however, although Burkitt (1962c) has stated (from information received from clinicians in Northern Nigeria) that it is virtually non-existent in the northern parts of this region.

\section{Area Covered by Present Survey}

The Northern Region of Nigeria is an area of some 281,800 square miles $(729,860$ sq. km.), extending from Ilorin in the southernmost part of the region, to Sokoto, Kano, and 